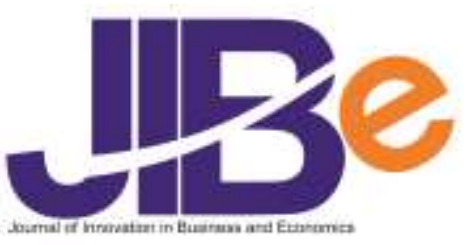

\title{
Business Models based Technology for Startup
}

Dhanar Intan Surya Saputra ${ }^{1}$, Kuat Indartono
Sitaresmi Wahyu Handani
Sitaresmi Wahyu Handani ${ }^{3}$

Department of Informatics, Faculty of Computer Science, Universitas Amikom Purwokerto, Indonesia ${ }^{1,2,3}$

https://doi.org/10.22219/jibe.v3i02.10168

\begin{abstract}
The many and existence of startups in Indonesia and the world continue to increase, along with the increasing use of technology and the internet. This encourages startups, newcomers to compete and survive to attract the attention of consumers. One of the determinants of startups' success is the business models, especially those related to technology. The use of the right business model will bring the impact of consumer or user trust on the startup. In this paper, the author presents a theoretical reviews related to some technology-based business models trends that can be used by a startup in starting his business as well as how to determine the right business model.
\end{abstract}

Keywords: Startup; business model

\section{Introduction}

Since the late 90s the internet has been predicted to be an important technology in economic and business growth. The internet will facilitate all aspects of business from marketing goods and services, accounting standards that are better and on the consumer side, consumers will get more competitive prices due to information disclosure. Study in Chinese provincial internet has significant role in promoting economic growth in China (Hasan, Wachtel, \& Zhou, 2009). Other studies also found evidence that the internet plays important role in economic after investment ratio, government ratio, adan inflation (Lio, Liu, \& Ou, 2011).

A study by McKinsey 2011 showed that the internet in the developing countries is able to support the GDP to $3.4 \%$ with household sector as its main activator. The household internet-based consumption in a global scope contributes $1.8 \%$ for the developed countries. Another research also showed that the internet has opened a wider opportunity for entrepreneurship and business activity (Suliswanto \& Rofik, 2019). One of the drivers of the internet-based economy is startup (Handani, Suyanto, \& Sofyan, 2016). Currently, there are at least four Startups in Indonesia that have successfully reached the level of unicorns, titles or a title given to Startups that have valuations of more than 1 (one) billion US dollars (Aldrich \& Ruef, 2018). The four unicorns are Go-Jek, Tokopedia, Traveloka, and Bukalapak (Eka, 2016).

The development of a startup in Indonesia is very rapid, the diversity of startup types is increasingly widespread and many in various types. This is evidenced by the current position of Indonesia which ranked number six in the world (Startupranking, 2018), ranked above the sequence of the highest of the United States, India, England, Canada, and Germany. The startup itself is a new startup company; its journey is still looking for the right business model, measurable, profitable, and can be enlarged continuously (Blank \& Dorf, 2012). This company started with the idea then look for the right target consumer then can develop quickly (Graham, 2012). The growth in the number of startups is also influenced by the success of business incubators in assisting and providing mentoring (Ahwarumi \& Sawarjuwono, 2017).

In looking for the right business model, startups often fail. Research on startup failure through case studies has been carried out by Bednár \& Tarišková (2018). The results show that the average years of experience and age of successful novice entrepreneurs are much lower than those of failed entrepreneurs. Successful entrepreneurs can expand their product footprint nationally and internationally, which gives them a platform for success and growth. Unsuccessful entrepreneurs cannot grow products and suffer at product launches and product adoption problems, which causes them to stagnate at the stage of emergence itself. As a result, while successful ones can penetrate markets gradually and steadily, those who fail cannot

${ }^{1}$ E-mail: dhanarsaputra@amikompurwokerto.ac.id

${ }^{2}$ E-mail: indartono@amikompurwokerto.ac.id

${ }^{3}$ E-mail: sita.handani@amikompurwokerto.ac.id 
capture the market itself. This shows that the right business model is the key to startup sustainability and growth (Bednár \& Tarišková, 2018; Kalyanasundaram, 2018; Reuver, Bouwman, \& MacInnes, 2009).

In this paper, the author presents several business models that can be applied to startups, so that later they can determine what business models they use, or even be able to innovate with existing business models with the products they have. Furthermore, this article also presents propositions regarding the steps to determine the right business model for a start-up. The plan offered is based on a literatures and business model that has been used and proven to work well.

\section{Start-up Business Models}

The existence of start-ups in Indonesia, in particular, will continue to grow in line with the development of Internet-based market share. However, many of the startups have not been able to compete until they have been able to achieve success, not even the few who fail or fall on the road to pioneer his efforts. Many factors are influencing, both technical and non-technical influences that affect success and success. With the right business strategy planning, it will help the company in analyzing the internal and external factors to formulate and design the right business strategy so that profit or profit will be achieved according to company objectives (Saputra \& Adnan, 2017). Every business undertakes four main things that are first created, produce goods or services, both market the goods or services. The third is the circulation of products by providing the best products or services to consumers and customers, the fourth as the last stage of the occurrence of financial transactions. The four things affect each other on the success and existence of the business is running or not. The path of the stage is at least also determined by the life of the right business model..

A business model is one of the main core of the success and success of a startup. Because of the good or unique idea and a good product but the startup has not found the right business model then there is a possibility that startup will be difficult to run the wheel and business processes. A good business model can start from the insight and knowledge of the user, the consumer and the target market as well as the motivation, thus achieving the goals and business success (Magretta, 2002). This will certainly determine the income, income or even investment that will be given to the startup. A business model consists of two essential elements, namely the value proposition and the operating model, each of which has three subelements, as in Figure 1. The elements describe what products will be offered to consumers, target consumer segments, products and types of services, financing and including the organization of such companies (Lindgardt, Reeves, Stalk Jr, \& Deimler, 2012).

Basically, businesses care about creating value and capture returns from that value, and The model is only a representation of reality. The business model as a representation of the core logic that underlies the company and strategic choices for making and capturing value in a network value.In the selection and use of business models, there are at least four components that affect each other and support the success or failure of business models used by the startup. The four components can be illustrated as in Figure 2 in the business model component diagram, which consists of Strategic Choices, Create Value, Capture Value and Value Network (Shafer, Smith, \& Linder, 2005). These components are integrated into each other so that it can help for the leadership of the company to be able to determine the right business model. The business model that startup use must match the main problem faced by the consumer or target market to be addressed, and of course can run better than the existing competitors. The business model can describe the value of a product that is created to be delivered to the consumer and on the other side the company or startup can know what the customer wants, how they want it, and how the company can manage to meet the customer's needs (Teece, 2010).

Choosing the right business model is crucial for startups; it can even be said finding the right business model is far more critical than finding the right idea. From the results of the analysis, data collection, review through previous studies, and observations of many startups that have been running, this paper show at least four business models.

\section{Dynamic Pricing}

Dynamic pricing models are pricing that varies following supply and demand. Dynamic pricing is a pricing strategy for goods based on demand and supply. The time of pricing can vary from daily to per second. Current technology is possible and very helpful in determining price changes. In fact, dynamic pricing is nothing new. In the past, price fixing was only influenced by the demand and supply in a place. How many people want to buy a product? How much inventory is currently available? Are these items easily damaged? Will the item be replaced with a newer version in the near future? These are all types of questions that play a large role in traditional pricing. The more data are evaluated the estimation of the optimum price for products. The time between increases in prices depends on industry and products, but it 
can be as routine as every day, or even every hour (Haws \& Bearden, 2006).

Dynamic pricing is an e-commerce and retail technique that incorporates variable pricing, not more traditional fixed pricing. The more data are evaluated the estimation of the optimum price for products. The time between increases in prices depends on industry and products, but it can be as routine as every day, or even every hour. American Airlines uses a variety of factors to determine price changes including booking dates and seat availability. At that time, prices were mostly based on supply and demand. Today, some of the biggest companies in the world including Amazon, Walmart, and Best Buy all use strategies in their e-commerce online stores. In Indonesia things are similar to start up hailing rides like GoJek and Grab. The more data are evaluated the estimation of the optimum price for products. The time between increases in prices depends on industry and products, but it can be as routine as every day, or even every hour (Jayaraman \& Baker, 2003; Kannan \& Kopalle, 2001).

According to Metcalfe (2017), the advantages of dynamic pricing are: 1) more competitive, using data to optimize dynamic pricing helps star0up to increase conversion rates and find optimal prices that match conversion rates and margins; 2) ability to suit competitive prices, 79 percent of consumers said, according to a survey by Ask Your Target Market, that respondents identify as purchasers of cheap goods. Seventy-eight percent said that before making a purchase, they compared prices from different sources. Therefore, in the online environment, it is necessary to adjust prices to remain competitive; 3 Increased versatility, Dynamic pricing flexibility allows e-commerce companies in their pricing strategy to target specific targets. Via dynamic pricing approaches, businesses may raise margins, sales, and even market share; 4) increased understanding trends, dynamic pricing enables firms to be more conscious and reactionary to trends in the industry. By offering discounts on the most popular items in the category, Amazon has taken advantage of large amounts of data and understand trends. Through ensuring that they have the lowest publicly available prices for goods, they cultivate the idea that they give the most economical rates.

Besides that, dynamic prices allow companies to react to changes in inventory. For example, when the supply of certain goods decreases, they can increase the price of the goods to reflect that fact and vice versa By offering discounts on the most popular items in the category, Amazon has taken advantage of large amounts of data and understand trends. Through ensuring that they have the lowest publicly available prices for goods, they cultivate the idea that they give the lowest prices. Last, Higher Sales Conversion Rate, Dynamic pricing provides a lot of data on what customers are paying for certain items. Most firms have to act as loss leaders for price increases under the initial purchase price. Since they have data to determine how the price of an item influences the conversion rate of sales deals, they can decide the optimum price for both items that contribute to the conversion.

\section{Freemium}

Freemium provides services or products in several categories, basic products are provided free of charge to consumers (Liu, Au, \& Choi, 2014). Under the freemium model, a company offers free services to customers as a way to build transaction sustainability in the future. By providing a free, primary level offering, companies are trying to build relationships with customers, which ultimately offer their offers, such as higher storage or usage limits, or a user experience that is free of advertising. Freemium has the priority to work well with small customer acquisition costs for internet-based businesses, but with high sustainability values. The freemium commercial enterprise model allows users to use the essential functions of the programs offered, the operator, or the operator for free, then the price to "upgrade" to the basic package. This is a well-known challenge for companies that are just starting because they are trying to lure users to their software programs (Wagner, Benlian, \& Hess, 2013). But there are some things that need serious attention to use this business model, some of them as revealed by Kumar (2014).

First, what must be free? Assume a startup has 20 features with five features free. Therefore, if the user wants to enjoy more than five essential elements, the user must pay. But need to be considered whether the additional features offered are really needed by consumers? Maybe there are other companies that offer the same features for free? Maybe also the basic features are enough? Some of these things concern for the level of success of the freemium strategy.

Second, communicate the product well. Communicating premium features to consumers is very important, lest consumers don't know there is premium content due to lack of communication either through unattractive advertisements or unclear notifications. Dropbox and LinkedIn are two good examples of this case. Dropbox has attracted 200 million users. Every person who registers gets two gigabytes of cloudbased storage for free. If people run out of space, they can pay $\$ 9.99$ per month (or $\$ 99$ per year) for 100 GB of storage. This is different from Linkedin, which offers premium features but does not yet feel it has a sustainable impact. Linkedin offers four premium subscriptions, some aimed at specific customer 
segments, such as recruiters or salespeople, and most display more in-depth search functions, better email capabilities, and more visibility into who has seen your profile. But the free and premium features are not yet apparent, if Linkedin can provide a clear boundary, it would be better for its revenue performance.

Third, would you open to creativity at all times? It is a mistake to see freemium as a customer acquisition tool only and remove the free version when a new customer starts joining or when the level of dive is changed. Users that enter late are generally more difficult to convert; therefore, in order to continue to improve, the value of the premium services must continue to be increased. Dropbox is an excellent example. It was primarily a service to back up files when it was launched in 2008. Then begin to offer shared folders, making them a platform for collaboration. New features allow smartphone and other devices to be automatically synchronized and images uploaded automatically. The user interface is also improving over time. The appeal of premium deals has been improved by each new feature.

Skype, a company that allows you to make video or voice calls over the Internet, is an example of a company using the freemium business model. There are no costs to build a Skype account, this app can be downloaded free of charge, and there are no fees for their basic services - calls to another device (or mobile phone or tablet). But you have to pay for more advanced services, such as calling to landlines or cell phones, even though the amount is small compared to conventional telephone companies ' costs. Another premium service is text messaging and video conferencing for as many as 10 users. Spotify, netflix and even YouTube are other businesses that use this technique. Most content will be provided free of charge, but some content will have to pay more. For consuming ad-free music, Spotify provides premium services, Netflix offers the latest movies that can be watched on smartphones, and YouTube has begun doing the same.

\section{On-Demand}

On-demand is a service system based on consumer demand (Fahland et al., 2009). When there are consumers who seek, require or order, the service provider will respond immediately (Osterwalder \& Pigneur, 2010). On-demand service has now become a thing that is close to everyday life. Ordering food through the application to request the website online is a common thing. On-demand services will also save costs because the goods produced must be sold and of course, this will significantly help the company's balance sheet. Business on demand is not easy because consumer demand is very volatile and difficult to predict. Therefore, you need to pay attention to the following things to run business on demand:

First, Products of daily necessities. If choose the idea of business on demand, then choose what is a daily necessity. So you can predict that business will still be needed because it is attached to everyday life, not like a seasonal business; second, speed and timeliness. Company must really pay attention to time management and take into account all the stages, for example starting from ordering, product preparation, and travel time to consumers. Optimization of time is an important key in business on demand because it greatly affects customer satisfaction; third, access services. Make access to services that make it easy for consumers. Adjust also to the market that you are targeting. If the consumer is comfortable in accessing the service without many obstacles, he will use it again. This will make consumers become loyal or loyal customers (Riyanto, 2016).

More over, do not be easily satisfied when your business on demand is above, because your business is very dependent on consumer demand. If you are not creative in making innovations, consumers will feel bored quickly or you will lose competitiveness with others. Which one is the most attractive and meets the needs of the service that consumers will prefer. Critical consumers will always compare. Not to mention if you use the price promotion strategy at the beginning of subsidies to attract the attention of customers, you must prepare another strategy when you lose consumers when prices become normal. Besides needing an innovation strategy, strong investor support will also save your business on demand when consumer demand is declining.

\section{Pay per use}

Pay per use is the same as conventional business, which customers pay according to what is used, without subscription (Ramdhan, 2016). The most common example is in the software industry. Expanding the compensation per-use plan of action to the product business is made conceivable by broad web entrance and expanded transfer speed. Like utilities, programming would now be able to be dispersed economically anyplace through ether. You have an enormous scale appropriation with low exchange costs and expanded insurance against robbery. In any case, things get all the more fascinating with regards to solid products, state autos. Until we have a "replicator" like Star Trek, you can't send it through the information pipe. In any case, the compensation per-use estimating model has entered this market (Murat Uenlue, 2016). 


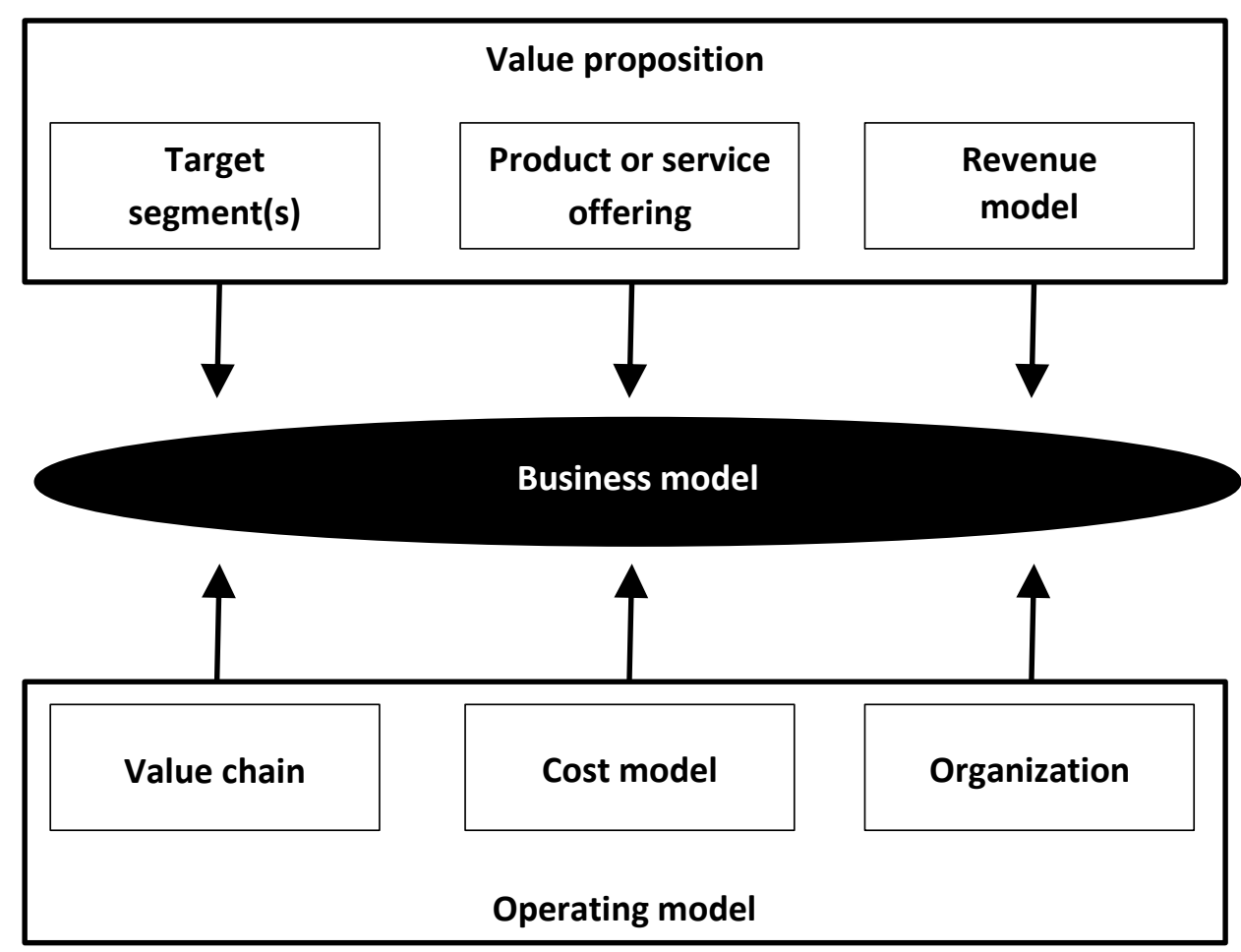

Figure 1. Business model component diagram (Lindgardt et al., 2012).

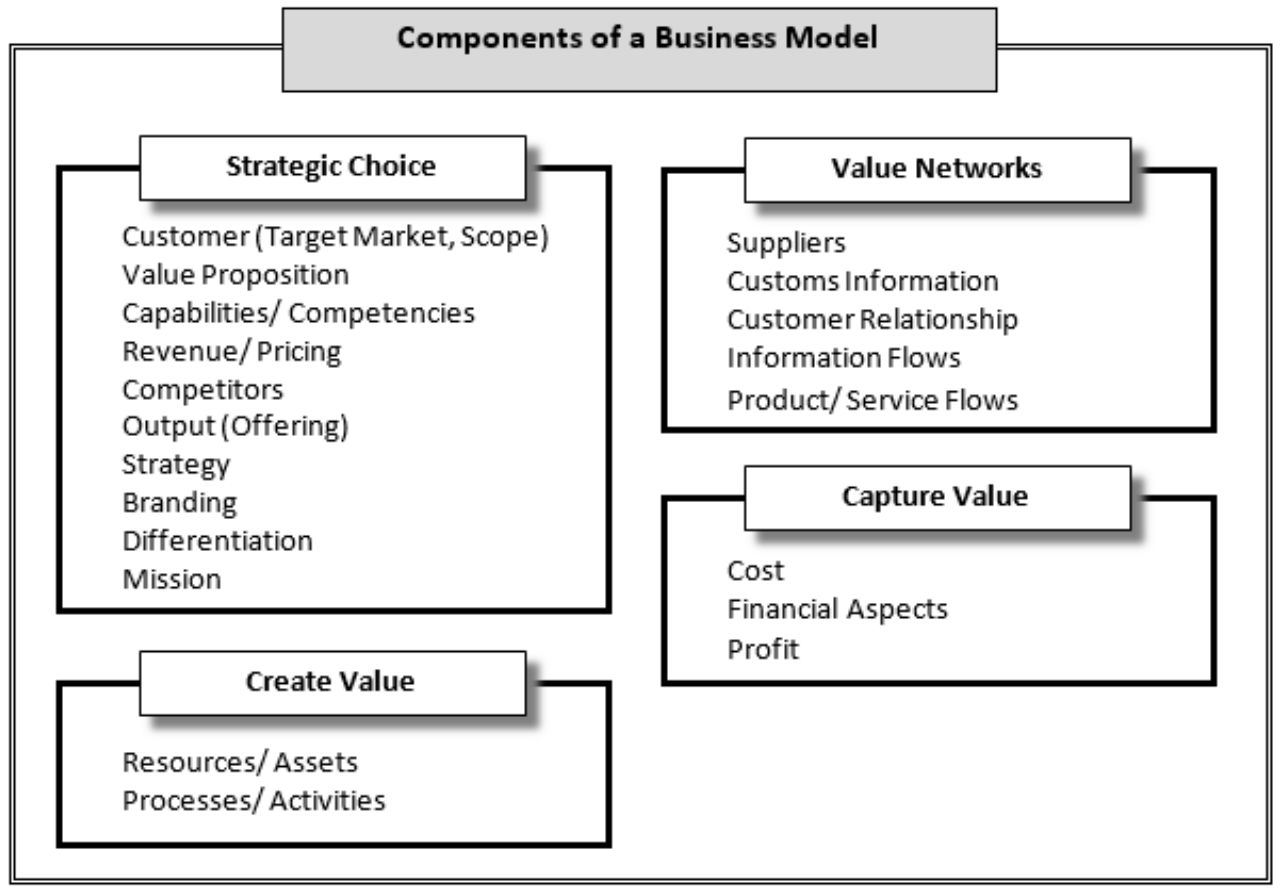

Figure 2. Components of business model (Shafer et al., 2005)

One model is Zipcar, Business Zipcar bodes well. This gives monetary advantages and addresses new market sections. This keeps away from enormous forthright installments (or assuming obligation) and ensuing devaluation misfortunes. This is helpful for understudies and other people who can't (or don't prefer) to purchase a vehicle. In space-restricted urban areas like Singapore, duties can without much of a stretch twofold the expense of purchasing a vehicle. In different urban areas stopping expenses Once you 
have the best-appropriate answers for advancement thoughts, we can make the following stride. Pay-peruse opens new market fragments. Be that as it may, it additionally accompanies some hazard. An unadulterated compensation for every utilization, for instance, can cause higher unpredictability in incomes. It should chance ripping apart, increasingly premium, or income creating contributions.

Another thing that is of concern in determining business models is the aspect of innovation. Business model innovations are very useful in the disruptive era. Business model innovation gives companies a greater chance to have their own consumer clusters and to avoid intense competition with competitors. Innovation of business models will make the company a scarf in front of competitors and will be free from monotonous competition and only rely on outdated strategies. Innovation will make start-ups more ready to face changes, starting from changes in regulations, market tastes and technological aspect. Innovation will also help resolve demand reductions, for example to reduce prices or reduce risk and ownership costs for customers (Lindgardt et al., 2012).

Studies also show that companies that can get through a crisis are companies that have innovation. Data reveal that during the recession of 1980, 1990 and 2000 the majority of companies experienced quite bad conditions. However, $9 \%$ of these companies not only recovered in less than three years, they even managed to become market leaders. The results of the research show that the recession not only comes with all its negative effects, but also provides an opportunity to increase competitiveness after the economy reverses direction. In fact, still from the same report, a significant difference between the group of companies that entered $9 \%$ with other companies is the preparation factor that prioritizes innovation.

Furthermore, Lingard divided the foundations of business model innovation into two main parts, namely the value proposition and the operating model. Value propositions include three basic things ranging from determining the target market, products or services offered, and revenue model. Meanwhile, for the aspect of the operating model consisting of an efficient and sustainable supply chain, an innovative financing model, and an effective company organization. Specifically for organizational aspects of innovation that are constantly needed for better performance (Hulpke, 2019). The combination of the proposition and operating model is believed to strengthen the business model chosen by the company. More details about the foundation of the business model can be seen in Figure 1.

\section{Determining the Business Model for Startup}

Startup business models are many and diverse, from simple to complex. Basically, any business model can be used, of course, tailored to the analysis of the products and target market targets, including through several steps. Based on literature as stated by (Lindgardt et al., 2012) and Shafer et al., 2005), this paper proposes at least five steps that can be done to choose the right business model for startup as follow Figure 3. 1) Market research, the idea of a startup might determine how big the market is. Perform analysis to see the existing market opportunities, can be obtained from the needs of potential customers or problems that appear in the community; 2) Observe competitors, It should be understood whether there are already competitors with the same service, provide more services or unique compared to existing competitors; 3 ) Determine the direction and goal of startup, before determining the business model to be used, it is important for a startup to be able to understand the vision of the mission, and the goals to be achieved and what services will be provided to customers through the startup; 4) determine connected stakeholders, determine who the parties will be related to and influential with the startup business; 5) Give more value, give value to related stakeholders when they work with a startup.

In addition to determining the Business Model, of course there are many factors that influence the success of Startup, such as: 1) market risk, startup can be said to fail or succeed due to the size of the market used. To run a business that can be sustainable is to enter into large markets and potential; 2) execution risk, that in building startups, there are certainly risks in product execution on the market. To be able to minimize the risks in product execution, it is necessary to build a team that is competent in their respective fields; 3) Technology Risks, to support success, can adapt technology from companies that are successful in applying it; 4) timing, namely choosing the right time in releasing or starting a business; 5) team / execution, the existence of a solid team will certainly build a strong business; 6) funding, the adequacy of funding to support the company's foundation. 


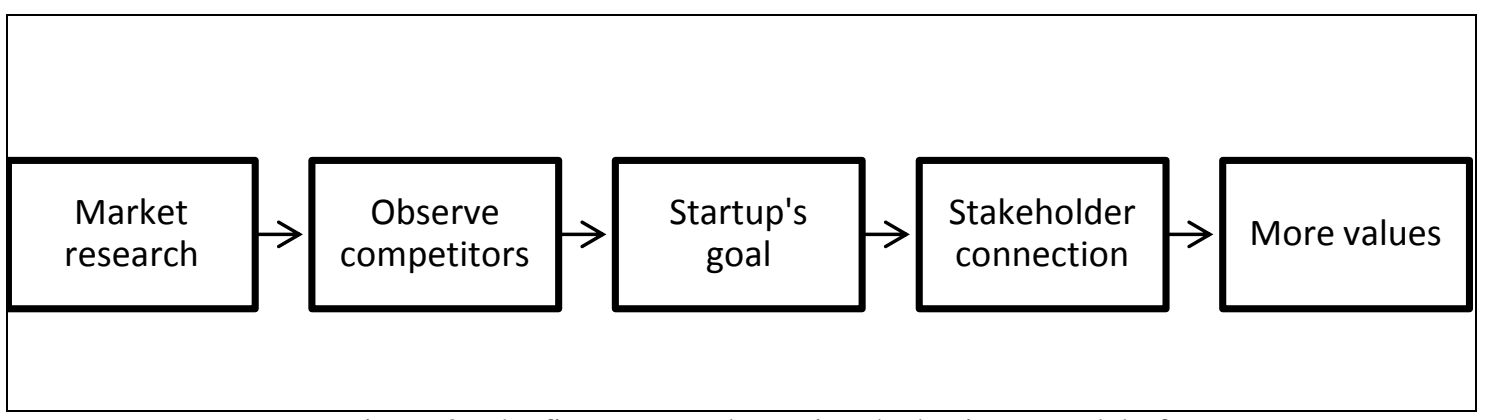

Figure 3. The five steps to determine the business model of startup

\section{Conclusions, suggestions and limitations}

The survival of a company, in this case, the startup is directly related to their ability to create and capture the opportunities that exist. Given the influence of using the right business model, there is the possibility of a startup will be faster to analyze and strategic decisions of the business. The decision to choose a business model will, of course, differ every startup, it can be influenced by many factors such as type, age, product and service, target and segment and so on. Choosing the right business model is likely going through many stages, this is because of the analysis was done by the startup itself. On the other hand, the successful use of a business model may not necessarily determine whether or not the success will be attached to a startup so that startup actors are required to continue to innovate on the products and services they provide to consumers or customers.

\section{Acknowledgments}

Special thanks and appreciation are submitted to the Research and Community Service Institutions of Universitas Amikom Purwokerto.

\section{References}

Ahwarumi, B., \& Sawarjuwono, T. (2017). Enhancing innovation roles of Pesantren business incubator in Pondok Pesantren Sunan Drajat. Journal of Innovation in Business and Economics, 1(02), 71-82.

Aldrich, H. E., \& Ruef, M. (2018). Unicorns, gazelles, and other distractions on the way to understanding real entrepreneurship in the United States. Academy of Management Perspectives, 32(4), 458-472.

Bednár, I. R., \& Tarišková, I. N. (2018). Indicators of startup failure. International Scientific Journal "Industry 4.0," 5(December 2017), 238-240.

Blank, S., \& Dorf, B. (2012). The startup owner's manual: The step-by-step guide for building a great company. BookBaby.

Eka, R. (2016). Mengenal Valuasi Startup dan Istilah "Unicorn."

Fahland, D., Favre, C., Jobstmann, B., Koehler, J., Lohmann, N., Völzer, H., \& Wolf, K. (2009). Instantaneous soundness checking of industrial business process models. In International Conference on Business Process Management (pp. 278-293).

Graham, P. (2012). Startup = Growth.

Handani, S. W., Suyanto, M., \& Sofyan, A. F. (2016). Penerapan konsep gamifikasi pada e-learning untuk pembelajaran animasi 3 dimensi. Telematika, $9(1)$.

Haws, K. L., \& Bearden, W. O. (2006). Dynamic pricing and consumer fairness perceptions. Journal of Consumer Research, 33(3), 304-311.

Hulpke, J. F. (2019). No Individual Creativity, No Organizational Innovation. Journal of Innovation in Business and Economics, 3(01), 41-48. https://doi.org/10.22219/jibe.v3i01.5972

Jayaraman, V., \& Baker, T. (2003). The Internet as an enabler for dynamic pricing of goods. IEEE Transactions on Engineering Management, 50(4), 470-477.

Kalyanasundaram, G. (2018). Why Do Startups Fail? A Case Study Based Empirical Analysis in Bangalore. Asian Journal of Innovation and Policy, 7(January), 79-102. https://doi.org/10.7545/ajip.2018.7.1.079

Kumar, V. (2014). Making "Freemium" Work. Retrieved December 30, 2019, from https://hbr.org/2014/05/making-freemium-work

Lindgardt, Z., Reeves, M., Stalk Jr, G., \& Deimler, M. (2012). Business Model Innovation: When the game gets tough, change the game. Own the Future: 50 Ways to Win from The Boston Consulting Group, 
291-298.

Liu, C. Z., Au, Y. A., \& Choi, H. S. (2014). Effects of freemium strategy in the mobile app market: An empirical study of google play. Journal of Management Information Systems, 31(3), 326-354.

Magretta, J. (2002). Why business models matter. Harvard Business School Boston, MA.

Metcalfe, L. (2017). What is Dynamic Pricing and Why is it Important? Retrieved December 31, 2019, from https://crealytics.com/blog/dynamic-pricing-important/

Murat Uenlue. (2016). No Title. Retrieved December 30, 2019, from https://www.innovationtactics.com/pay-per-use-business-model/

Osterwalder, A., \& Pigneur, Y. (2010). Business model generation: a handbook for visionaries, game changers, and challengers. John Wiley \& Sons.

Ramdhan, H. (2016). Startup Business Model. Penebar Plus.

Reuver, M. de, Bouwman, H., \& MacInnes, I. (2009). Business models dynamics for start-ups and innovating e-businesses. International Journal of Electronic Business, 7(3), 269. https://doi.org/10.1504/ijeb.2009.026530

Riyanto, T. (2016). Hal yang Perlu Diperhatikan dalam Business on Demand. Retrieved December 30, 2019, from https://zahiraccounting.com/id/blog/hal-yang-perlu-diperhatikan-dalam-business-ondemand/

Saputra, D. I. S., \& Adnan, A. F. (2017). Analisis dan Rekomendasi Strategi E-Commerce Pada Usaha Kecil Menengah Batik Sokaraja. Probisnis, 10(1).

Shafer, S. M., Smith, H. J., \& Linder, J. C. (2005). The power of business models. Business Horizons, 48(3), 199-207.

Startupranking. (2018). Startup Ranking.

Suliswanto, M. S. W., \& Rofik, M. (2019). Digitalization of Micro, Small \& Medium Enterprises (MSMEs) in East Java, Indonesia. Muhammadiyah International Journal of Economics and Business, 2(1), 3443. https://doi.org/https://doi.org/10.23917/mijeb.v2i1.9380

Teece, D. J. (2010). Business models, business strategy and innovation. Long Range Planning, 43(2-3), 172-194.

Wagner, T. M., Benlian, A., \& Hess, T. (2013). The Advertising Effect of Free--Do Free Basic Versions Promote Premium Versions within the Freemium Business Model of Music Services? In 2013 46th Hawaii International Conference on System Sciences (pp. 2928-2937). 